\title{
Iuri Druzhnikov
}
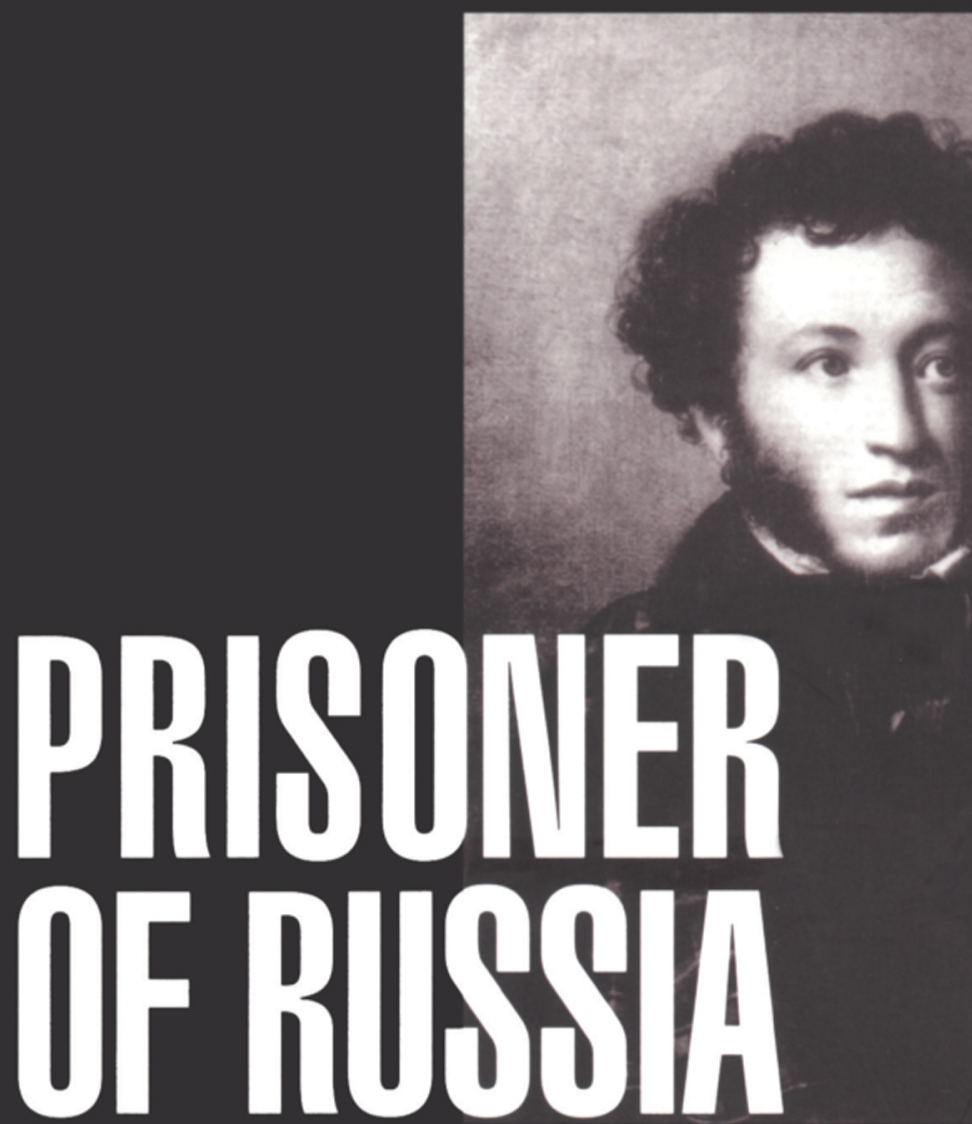

Alexander Pushkin and the Political Uses of Nationalism 


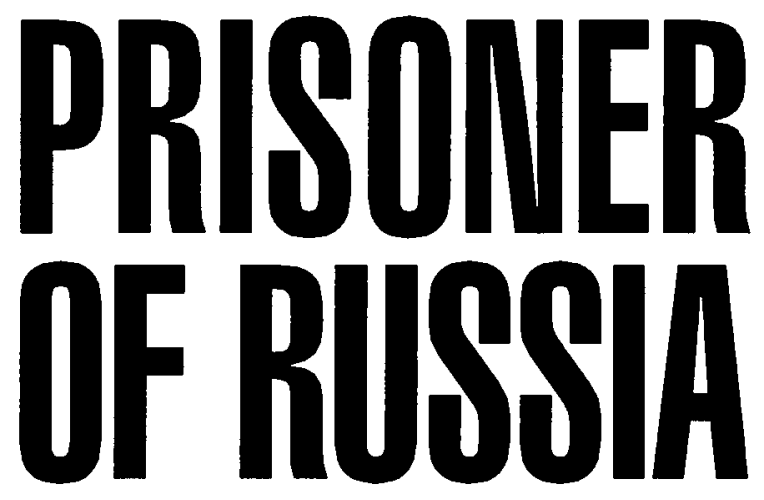




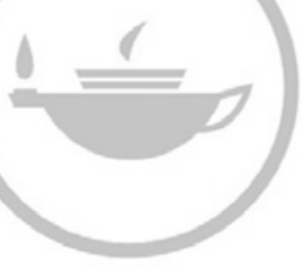

\section{Taylor \& Francis Taylor \& Francis Group}

http://taylorandfrancis.com 


\section{Yuri Druzhnikov}

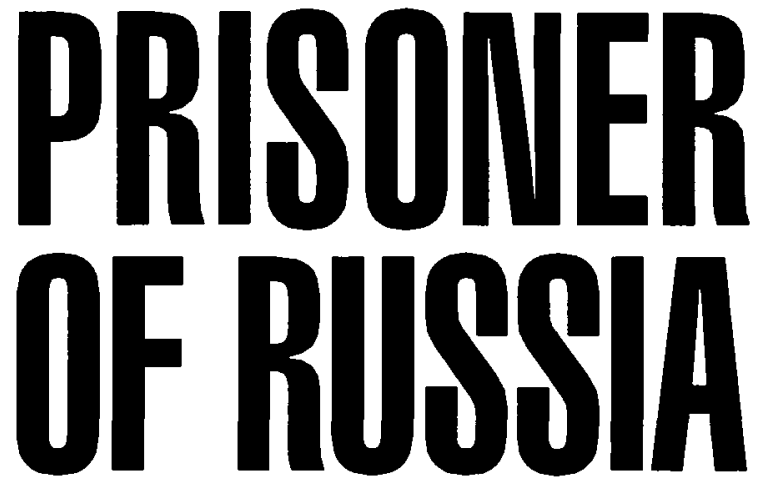

Alexander Pushkin and the Political Uses of Nationalism

\section{Translated by}

Thomas Moore \& Ilya Druzhnikov

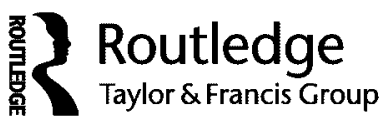

LONDON AND NEW YORK 
First published 1999 by Transaction Publishers

Published 2017 by Routledge

2 Park Square, Milton Park, Abingdon, Oxon OX14 4RN

711 Third Avenue, New York, NY 10017, USA

Routledge is an imprint of the Taylor \& Francis Group, an informa business

Copyright $\mathbb{C} 1999$ by Taylor \& Francis

All rights reserved. No part of this book may be reprinted or reproduced or utilised in any form or by any electronic, mechanical, or other means, now known or hereafter invented, including photocopying and recording, or in any information storage or retrieval system, without permission in writing from the publishers.

Notice:

Product or corporate names may be trademarks or registered trademarks, and are used only for identification and explanation without intent to infringe.

Library of Congress Catalog Number: $98-52062$

Library of Congress Cataloging-in-Publication Data

Druzhnikov, IUrii, 1933-

[Uznik Rossii. English]

Prisoner of Russia : Alexander Pushkin and the political uses of nationalism / Yuri Druzhnikov ; translated by Thomas Moore and Ilya Druzhnikov.

p. $\mathrm{cm}$.

Includes bibliographical references and index.

ISBN 1-56000-390-1 (alk. paper)

1. Pushkin, Aleksandr Sergeevich, 1799-1837. 2. Poets,

Russian-19th century-Biography. 3. Literature and state-RussiaHistory-19th century. 4. Political persecution-RussiaHistory-19th century. I. Title. PG3350.D7813 1999 $891.71^{\prime} 3-\mathrm{dc} 21$

[B] 


\section{Contents}

Foreword

vii

\section{Part 1: A Willful Exile}

Translated by Thomas Moore

1. Pushkin Intends to Go Abroad 3

2. "Send Him to Live in Göttingen" 23

3. The No-Exiter 33

4. Conflict of Mind and Heart 43

5. The Willy-Nilly Vacationer 67

6. Kishinev: Point of Transit 77

7. To Greece with the Greeks $\quad 89$

8. Running Off with Gypsies 99

9. Hope for War 107

10. Pleas and Rejections 119

11. Odessa: Across the Free-Port Line 135

12. Down Smugglers' Routes 145

13. Money for Departure 155

14. From Rainclouds to Sunny Skies 165

15. "I Carry Death Around with Me" 181

16. The Hour of Farewell 191 


\section{Part 2: Dossier on a Runaway}

Translated by Ilya Druzhnikov

17. Mikhailovskoye: A Deal between Brothers

18. Your Unfaithful Servant

19. Legally, for Medical Reasons

20. A Cabal with Tyranny

21. Petition after Petition

22. Hope and Fear

23. On a Leash

24. Moscow: "Here's Your New Pushkin" 307

25. The Hangover after Glory 315

26. The New Old Strategy 333

27. The Unmarked Jubilee 347

28. To the Army or to Paris 359

29. "I Have the Honor to Inform" 373

30. Genius and Villainy 385

31. The Not-Quite-Secret Departure 403

32. Caucasus: Crossing the Border 417

33. "Missing My Chains" 425

Selective Bibliography 437

Index 443 


\section{Foreword}

Alexander Pushkin "has, no doubt, carried with him to the grave a great mystery," a mystery we are all too glad to pursue and explore. ${ }^{1}$ Dostoyevsky brought to our notice this message in 1880, and until now, at least one enigmatic aspect of the great Russian author's life and work has never been explored in earnest by Pushkin scholarship. It has become the central theme of two chronicles under a common title The Prisoner of Russia.

It would appear that by now everything which pertains to Pushkin-as a poet, novelist, literary critic, historian, journalist, even human being-ought to have been explored in exquisite detail. A century-and-a-half of research has unearthed more about him than the poet had ever known about himself. His views regarding literature, philosophy, religion, economics, even medicine, have been exhaustively explored. Scholars have calculated which idiomatic expressions he used, and how frequently; the range of every pistol shot he ever fired in a duel has been studied; we know how long his fingernails were and which medicines he used for what particular ailments. His debts have been accounted for to the last kopeck. Pushkin's ancestry has been charted for six hundred years prior to his birth. There exist catalogues of women whom he honored with his attentions; whole books of anecdotes about him have existed for over a century. Detailed maps have been compiled of his travels, and chronological studies delineate his entire existence, from his first breath to the last. An educated individual in Russia knows Pushkin's life in more detail perhaps than his or her own.

We might ask a question, though: which of the many alternative interpretations, familiar and obscure, is the real Pushkin? Is it the poet who became a national shrine, the "Central Artist," as Ivan Turgenev had once described him?2 Besides being, clearly, the key figure in the Russian literature, Pushkin is also the centerpiece of Russian culture. This centrality is precisely what makes Pushkin such a tempting target for co-optation by every government, party, or a social group searching for a historical footing to shore up its beliefs.

Exploited as a path to achieve one's literary objectives, Pushkin has be- 
come a pawn in many political, religious, and personal struggles. At different times, he was considered a philosophical idealist, an individualist, a Russian shellingian, an Epicurean, a representative of Natural philosophy, a true Christian (Russian Orthodox), a monarchist, a radical atheist, a Mason, mystic, pragmatist, optimist and pessimist. Two or more self-contradictory labels have often been applied simultaneously. During the Soviet era, he was labeled a poet of the gentry; later, after shedding his noble origins, he became a revolutionary poet-a Decembrist, a materialist, and even, in accordance with the Marxist ideology, a historical materialist.

The proponents of all these points of view are, to some degree, correct. As the philosopher Semyon Frank once noted, Pushkin's experience was "multilayered." 3 Genius is necessarily somewhat eclectic, and among Pushkin's works, manuscripts and the marginal notes in his books, one can find evidence of the poet dallying with any number of subjects.

The number of facts amassed by Pushkin scholarship has increased exponentially, while conceptual interpretations of the factual data have, at different times, been subject to various ideologies feigning true scholarship. In the Soviet era, the official science of Pushkin studies became a bureaucratic apparatus designed to suppress any semblance of unorthodox thought. I need only remind the reader of the governmentally decreed anniversaries of Pushkin's life, the standardized biographies, the carefully slanted selections of his works published in millions, of contemporaries' memoirs, abridged of any semblance of dissent.

In addition to acquiring the copy rights to Pushkin's work, the Russian state has, to some extent, appropriated the man's biography-interpreting it in such a way as to appear suitable for every subsequent era's dominant ideological paradigm. Criticism of Pushkin, so useful to the poet's rising popularity while he lived, has later become the equivalent of an assault on a national monument. Even the journalist Ksenofont Polevoy, one of the first to recognize Pushkin's immortal services to the Russian language, has remarked sadly, "I know I need to be very careful when speaking of Pushkin. Lately there have been people trying to represent me as some kind of hate-monger toward our great poet and a slanderer of the ethics of his personal life."4

To some extent, the real poet has been lost-his genius, his all too human desires and weaknesses, are transformed more and more to conform to an image useful to those in power. He has become an idol, replicated in countless monuments, in the names of towns and streets; an embodiment of the Russian spirit itself, one of the official heroes, a symbol of Imperial Russia. After the October Revolution of 1917, a few thoughtful Pushkin scholars attempted without success to reverse this tide. Boris Tomashevsky, for example, expressed his dismay that "this contrived Pushkin plays such a great role in the literature."5 Nevertheless, the real Pushkin had already been calci- 
fied, mummified-his image turned into an icon for worship, insulated from the doubts and inquiries of skeptics.

Pushkin can hardly be blamed for his transformation into a fulcrum for chauvinist (to use the word in its original sense) propaganda, designed to suit the lowest common denominator. It is the tragedy of the Pushkin scholarship that its practitioners were compelled to conceal the truth, to divert their emphasis from the salient points, and to help produce such popular myths in place of genuine scholarship. Attachment to one's homeland, so natural to most people, became in Pushkin's case a tool of the dominant ideology. While still alive, he submitted to the compunction of glorifying the Empire; dead, he is again forced to lend his voice to the Russian government, extolling its stability and viability.

The real Pushkin had never succeeded in experiencing the world beyond the borders of Russia. Having begun his plans for escape immediately upon graduation from the Lyceum, Pushkin continued his attempts throughout the duration of his exile in Kishinev, Odessa, and Mikhailovskoye. When the poet returned to Moscow, he had hoped that his freedom of movement would be restored to him; in fact, to obtain it, he was compelled to escape to the Caucasus, to attempt to reach Europe through Turkey. But the chains binding him to his homeland only stretched taut, without braking. There was no escape.

We are faced with a question, not yet posed by Russian scholars which is relevant in this, typically Russian, context. The answer to this question impacts to a great extent the official myth of Pushkin as a patriot-poet, a myth which has been forged over one-and-a-half centuries. We must determine whether Pushkin intended to go abroad, only to return again, or whether he planned to leave the country forever, that is, to emigrate. The noted Pushkin scholar Pyotr Guber (who ended his life in Stalin's labor camps and was "rehabilitated" posthumously), once remarked that Pushkin was possessed with a "burning desire" to journey abroad. ${ }^{6}$

In the first few years after graduating from the Lyceum, Pushkin was hired by the Ministry of Foreign Affairs, and intended to serve abroad as an official of the diplomatic corps. Later, he wanted to travel in order to broaden his knowledge of the world, as so many of his contemporaries were wont to do. In all likelihood, upon returning from such a journey, Pushkin's thoughts would have resembled those expressed by his colleague and friend Evgeny Boratynsky in a letter to his mother: "I will return to my homeland cured of many preconceptions, and with a complete tolerance for our true shortcomings, which we often happily exaggerate."7

Yet, unlike all of his fellow literati, Pushkin was denied the permission to leave. It was only then that the poet began in earnest to explore possibilities of leaving his homeland in secret. As we know, he conceived numerous plans 
for escape. Had he done so, it would have been impossible for him to return. Once the border was crossed illegally, all of a fugitive's bridges were burned behind him. Coming back would only result in a prolonged and melancholy journey to Siberia. Pushkin often found himself reflecting on the likelihood of such a trip.

An escapee automatically became a fugitive, a political émigré, an outcast. In the past several centuries, Russia has produced a number of them. Meanwhile, government propaganda was likely to use these people as universal scapegoats, burn them in effigy as traitors, splitters, and enemies of the people. As a rule, an expatriate only returned to his homeland in one of the two ways: after either significant changes in the political landscape, or death, to be buried under native soil. Some prominent émigrés became custodians of those aspects of their cultural heritage which were banned at home. Those for whom escape had failed, rotted away in the Siberian forced labor camps.

There were examples of both in Pushkin's time. Pushkin, naturally, kept abreast of such events, was acquainted with other fugitives, and often imagined himself in their place. There is little doubt that, once Pushkin had resigned himself to becoming a fugitive, he also understood the impossibility of his return.

Searching through the annals of Russian literature, one is hard-pressed of find another author as simultaneously obvious and enigmatic as Pushkin. One of the poet's habits was to trace his own profile on the margins of his manuscripts. He drew hundreds throughout his life, and fascinating collections have been assembled from the surviving manuscripts. A number of books have been written on the subject, yet none of them answer the simple question of why, among hundreds of self-portraits he has drawn, each is oriented toward the West. Who or what stood in the way of the poet realizing at least one of his numerous plans for emigration? Was it the Tsar? The secret police? A sense of duty to his homeland? Women whom he loved? Money?

Clearly, even in a genius's life there exists an enormous gap between a desire and its realization. By nature, the poet is a fugitive, and if circumstances preclude his escape to an exterior, then he is forced to flee from himself. For Pushkin, Russia had grown too cramped and stifling, and he knew where he would rather be.

If Pushkin often described himself as a "runaway" and an "exile," it is somewhat paradoxical. An exile, of course, is an individual forcibly removed from society, while an escapee is someone who leaves clandestinely, and of his own volition. The poet, however, considered himself an escapee even when he was in exile. He described himself as "banished" even in Moscow or Petersburg. This is his characterization of himself: 
Unhappy with the world, with life, and with himself

A soul full of thought (II.63). ${ }^{8}$

His lone desire to see the world was suppressed, forbidden, presented a crime. Prevented from experiencing Europe, Africa, or China, he was forcibly isolated from much of the world's culture. The "sun of Russian poetry" had risen in the East, and wanted to set in the west, but this was not to be. Driven to desperation, shortly before his death, the poet expressed this attitude toward his homeland: "... The devil has prompted my being born in Russia with a soul and with talent!"9

Pushkin's significance to the world outside has been consistently exaggerated and distorted within Russia. "We, the Russians, cannot really blame Europe for not noticing Pushkin. We were the ones who encircled him with borders," wrote a researcher in the West. ${ }^{10}$ How would Pushkin have been perceived in Europe, had he only lived another quarter of a century? Another Gogol or Hertzen, perhaps? We shall never have an answer to this question.

The time has come for a new approach towards Pushkin, for the scholarship surrounding this great figure to evolve beyond its tired scholasticism, its ideological taboos, and its outdated ties to mythology. Pushkin's life, lived in a tragic state of imprisonment, can neither be understood, nor interpreted irrespective his desire to see the West. Yet, this is precisely the aspect of his biography which has always been relinquished to the shadows. The concept of a book dedicated to Pushkin's "exit file" is designed to remedy the situation-it is as new for the general reader as for the literary historian. Apart from a single article published before the Russian Revolution, the topic has not been studied at all. ${ }^{11}$ Its importance, though, is enormous. Even Dostoyevsky, intently focused on the subject of national consciousness, has remarked of Pushkin: "Our longing for Europe, even with its obsession and extremism, was not only legitimate and reasonable in its foundation; it was popularly accepted, coinciding with the urges of the people's soul, and in the end dubtlessly serves a higher purpose as well."12 The enormous amount of Pushkin literature available today allows for reinterpretation of documents which have lapsed into obscurity, revival of memoirists' testimony and archival materials. One should be able to compare viewpoints, to concentrate on their blank spots, and to discover the contradictions. In doing so, one opens the possibility for new hypotheses replacing the so-called facts.

It has often been remarked that by studying a writer out of the context of his chronological and social surroundings, one can mistakenly ascribe to him or her those innovations which rightly belong to the literary period as a whole. In this book, I have consciously avoided trying to produce a comprehensive biography and analysis of Pushkin's work. Still, the consideration of a writer's biography from a single vantage necessarily lends itself to a certain 
bias, to the hyperbolization of a given topic at the expense of other themes. One is forced constantly to omit details not directly relevant to one's main goal. As the great Russian historian Vasily Kluchevsky once noted: "One always wants to say too much about Pushkin, and one always ends up saying many extraneous things, leaving out the important ones."13

It has not at all been my intention to have this book taken as an attempt to undermine Pushkin's significance, particularly at present, when he remains the solitary giant of the Russian cultural heritage. Speaking the truth, purging the past of many layers of deception, can do nothing but strengthen the cultural values of the nation. Pushkin was a master, whose efforts helped drag the Russian medieval literature directly into the modern age. He was doubly masterful for having created his work while forcibly isolated from the vital influences of the Western civilization. He bridged the gap between Russia and the West. As Vikenty Veresayev, a distinguished Pushkin scholar, had once justly noted, "it is boring to study the life and personality of great individuals while genuflecting before their accomplishments." 14

\section{Notes}

1. Dostoyevsky 1984, vol. 26, 149.

2. Turgenev 1962, vol. 10, 303.

3. Frank, 1967, 88.

4. Pushkin v vospominaniyakh 1974, vol. $2,52$.

5. Tomashevsky 1925, 51 .

6. Guber 1923, 10.

7. Poety pushkinskogo kruga 1983, 502.

8. If not specified the notes in parentheses are given in the text throughout the book from: Pushkin. Polnoye sobraniye sochineny v desyati tomakh, 4th ed., Leningrad, 1977-79 (volume and page).

9. Pushkin $1967,768$.

10. Bylov 1953, 32.

11. In the beginning of this centry, during a time noted for its freedom of expression, Pushkin scholar Mstislav Tsyavlovsky dedicated a small essay to the poet's vain attempts to go abroad: "Toska Pushkina po chuzhbine," Golos minuvshego, 1916. A censored version of this article was printed in a collection of this scholar's work: Stat'io Pushkine, 1962.

12. Dostoyevsky, 1987, vol. 26, 131.

13. Pushkin. Statyi i materialy ,1925, 12.

14. Veresayev, 1929, 87. 


\title{
Part One
}

\section{A Willful Exile}

\author{
Translated by Thomas Moore
}




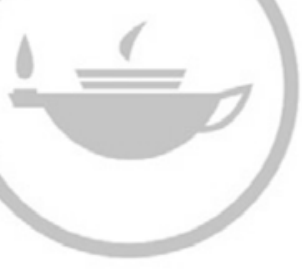

\section{Taylor \& Francis Taylor \& Francis Group}

http://taylorandfrancis.com 


\title{
1 \\ Pushkin Intends to Go Abroad
}

\author{
"A callow lover of all foreign nations, \\ Forever calling to account my own..." \\ -Pushkin. November 30, 1817 (I.281)
}

One summer evening in 1817 in St. Petersburg, Nikolay Gnedich, the eminent Russian poet and future translator of Homer's Iliad, introduced two poets to each other during an intermission at the theater. One of them, Pavel Katenin, was a playwright and Guards officer who had achieved the rank of colonel in only three years. The other poet was a young man accompanying Gnedich, who introduced him to Katenin: "You know him by his talent-this is the Lyceum's Pushkin."1 In reality, Pushkin had already achieved tenth-class rank-collegiate secretary - and had been taken onto the staff of the Ministry of Foreign Affairs. Gnedich of course meant "Lyceum's Pushkin" in the sense of "that very poet who became famous while still at the Lyceum."

Apparently the conversation between them touched upon continuing their acquaintance, but that wasn't to be at that time. "I told my new acquaintance," Katenin wrote in his memoirs, "that, to my regret, I was being transferred to Moscow the day after next with the First Battalion of the Guards Regiment. Pushkin replied that he would also soon be setting out for foreign parts; we wished each other a pleasant journey and parted." 2

There is no doubt that Katenin was recalling Pushkin's exact words. Researchers have more than once confirmed the authenticity of Katenin's memoirs. Yuri Lotman calls him an authoritative witness. ${ }^{3}$ Katenin doesn't indicate the date he met Pushkin, but most likely 
Pushkin mentioned going away himself at the August 27 premiere of August Kotzebue's The Power of an Oath, featuring the tragic actress and beauty Yekaterina Semyonova. Gnedich was her elocution instructor, while Katenin and Pushkin were both pursuing her, not suspecting their rivalry.

That flirtation doesn't concern us, and we won't linger over it. We will only note Pushkin's remarks to the effect that he would soon be setting out for parts unknown. The words chuzhie kraii (foreign parts) and chuzhbina (strangerdom) were synonymous with "abroad." No negative connotations adhered to them in the educated society of those times.

So by the time of his graduation from the Lyceum (and possibly even earlier, while still attending it, but we have no knowledge of that), Pushkin had already begun thinking of travel abroad. He was just eighteen.

We are highlighting that remark of Pushkin's, that was recorded by Katenin, because the poet's biographers have paid no attention to it and have made no mention of his plans to go abroad immediately after graduation. Mstislav Tsyavlovsky, a leading Pushkin scholar, discussed the intentions of the poet to go abroad only in his first and apparently last article on this painful topic in 1923, about which we will be saying more later. ${ }^{4}$ Twenty years later, Pushkin would be dead, but in that whole time the great Russian poet never once made it beyond the bounds of the empire - the very fact whose importance for him and for the country he lived in we will be investigating.

Ancestral voices were strong in Pushkin. Perhaps that is why his foreign origins, so to speak, are important. Up to the end of the nineteenth century, a particular ancestor of Pushkin's was considered first to be an African, and then an Abyssinian, that is, a native of the country now known as Ethiopia. It is presumed that he came from a noble family. Today it has been shown that the poet's great-grandfather Ibrahim, nicknamed "the Blackamoor of Peter the Great," was apparently born not far from Lake Chad, on the borders of contemporary Chad and Cameroon in Africa. ${ }^{5}$ Ibrahim had been a child at the outset of a war with Turkey. The Turks carried off trophies of valuables and slaves, among whom was the future poet's ancestor. At that very time, black-skinned servants had become fashionable in Russia.

At the end of the seventeenth century, the boy was given as a gift to Peter I, and christened Abram Hannibal. Curiously enough, though he 
had been a slave in Turkey, he became a free man in Russia-not at Peter's whim, but by a law then promulgated. Later on he was made a general for his intelligence and devotion. Abram's first marriage was to a Greek woman, and subsequently he married a German or Swede by the name of Christina Scherberg, with whom he had children. Abram and Christina's son Iosif, later Osip, was Pushkin's grandfather. ${ }^{6}$

These ancestral voices might have been no small factor in his desire to leave the country of his birth, or might have been of no significance at all. This fact has never been considered by Pushkin scholars. Apologists for the regime at the height of flight from the Soviet Union liked to ascribe a desire to emigrate to the amount of foreign blood in one's veins. During particular periods of political controversy, either Pushkin's pure Russianness or his "internationalism" or "brotherly solidarity with other peoples" was stressed, since blacks were symbolic of the oppressed in capitalist countries. Mayakovsky, thinking of the poet's negro origins, wrote: "After all, Pushkin wouldn't be allowed even now into a respectable hotel or occasion in New York." Pushkin's origin served to prove to Soviet readers how bad life was in America and how good it was in the USSR.

Contrary to the traditional perception, Pushkin's hair wasn't black, and after he had fully grown, it stopped being curly. He didn't cut it, and it hung to his shoulders. "I have a fresh complexion and fair hair," he described himself coquettishly in a poem in French when he was fifteen years old (I. 80). He also said that he wanted to dye his hair black to look more like an African. The poet's biographer Pyotr Bartenev recorded from oral recollections of relatives that Nadezhda Osipovna Hannibal, Pushkin's mother, had dark spots on her body. ${ }^{8}$ They called her "the Creole." Perhaps these spots were signs of imperfection in the pigmentation of her skin and not her origin. As for her nickname, it designates only the offspring of European colonials in Latin America. Nadezhda Hannibal was half Swedish, or as a Soviet source vaguely hinted, there were Varangians on her mother's side. ${ }^{9}$ The ancestors of the other Pushkin grandmother, Olga Checherina, his father's mother, were emigrants from Italy.

Pushkin's father's family stems from a Prussian emigrant, Radshi (or Rachi), who settled in Russia during the reign of Alexander Nevsky. Pushkin spoke of this in his journals. After Pushkin's canonization, people began to write that Radshi wasn't of German, but Slavic origin. 
But does this have any vital significance? Only for the myth, it seems to us. As a matter of fact, despite all the influence of genetics, what is important is who Pushkin felt himself to be. Pushkin considered himself a Russian nobleman, and that was his nationality. The cultured Pyotr Vyazemsky, a man more cosmopolitan than Pushkin, tried to assure him that at particular times in history Russianness could be something to be ashamed of. But Pushkin's pride in his Russian birth also had a right to exist.

Nevertheless, Pushkin inherited some of his great-grandfather's traits, and not always the best of them. While Abram was still a boy, there were attempts to ransom him, but the tsar wouldn't give him up, and later sent the youth to study in France. With delight bordering on excess Pushkin describes his foreign escapades, where "nothing could compare with the frivolousness, craziness, and splendor of the French" (IV. 7). Peter I summoned Abram home, but he kept on with his studies, sowed his wild oats, enlisted in the army, and fought for France. He revealed his readiness to return-if he was sent the means to do so-only after having squandered all his money and finally even getting mixed up in amorous intrigues. It was done. Pushkin never got around to writing about his great-grandfather's life in Russia, his journals having been cut off so abruptly.

There is a suspicion that Peter didn't make Abram a courtier by accident. The tsar was battling with the Turkish empire, but that didn't exclude him from having designs not just on India, but on Abyssinia as well. For that circumstance he had to have, thinking in contemporary categories, a ready puppet. Peter died, leaving his schemes to succeeding masters of the empire. In any event, Russia's influence over Africa was infinitesimal in Pushkin's day. But for him, Africa remained a part of that abroad that he called his own.

Pushkin's social origins theoretically gave him definite privileges of travel out of the country, but those origins should be looked at. Where exactly in Moscow Pushkin was born remains unclear, and has been cropping up as a subject of dispute for a century and a half-as rickety as any Russian history. It is established only that he was born in Nemetskaya Sloboda and that he was baptized in the Church of the Epiphany in Yelokhovo. The author lived for a couple of years in that formerly German suburb after the Second World War-everything there was as it had been at the end of the century before last, except for tramcars clattering alongside horsecarts, down crooked lanes run- 
ning through ruins where people were crawling in and out of every crack in the wall. It goes without saying that there were no more German university professors or other Russified foreign intellectuals left, most of the streets had been renamed, and the homes of the grandees and rich landowners were crammed with proletarians and rustics.

In Pushkin's day it was a prestigious German district not far from the center of Moscow, where 300,000 people lived then (in all of Russia under Peter there was about thirteen million people, and under Alexander I about forty million). ${ }^{10}$ The population of the empire didn't grow due to fertility so much as to the acquisition of new territories. Civilization penetrated unhurriedly: the first aqueduct, similar to those of the ancient Romans', was built when Pushkin was five years old, and the populace began to draw water by horse-carried barrels not from the river, but from a fountain in the middle of town.

Although Pushkin's father, Sergey Lvovich, was the son of a rich landowner, little of that wealth was left to the grandson. To soothe his vanity and preserve his upward mobility, he had to confirm the distinction of his bloodline. The poet would go on about his 600-year-old roots, but he was mocked for it. Among Pushkin's ancestors were those who had signed the electoral deed of Mikhail Romanov's tsarship. The poet inserted his forebears into his artistic descriptions of Russian history. A genuine genealogy of Pushkin's Russified ancestors was compiled before the end of the last century by M. Muravyev. ${ }^{11}$ It came to light that his father's pedigree was even richer than the poet had imagined.

Among his ancestors were distinguished diplomats and some who carried out special foreign missions for the tsar. Vasily Slepets escorted Princess Elena to the Lithuanian Empire in 1495; in 1532 Vasily Pushkin went as ambassador to the Kazan Empire, Yevstafy Pushkin to the Swedes, Grigory to the Poles and Swedes, Stepan as ambassador to Poland, and Aleksey Pushkin was a senator and envoy to the Danish court. Only towards the end of the seventeenth century did one Matvey Pushkin resist the idea of sending his children abroad to study, which sent Peter into a rage. Pushkin's genealogy would seem to have encouraged him to embark upon a diplomatic career.

It is strange but true: Pushkin recalled his early years with reluctance. He didn't like the home where he was born, his family, or his parents. Not even once did the poet mention his father or mother in his 
poems, although he immortalized almost everyone else. In Eugene Onegin, for instance, he speaks in detail about the upbringing of his hero, his teachers, father, even uncle, but not a word about his mother. Nor has correspondence between the poet and his parents survived. He called the Lyceum his native abode, his birthplace. On his deathbed, Pushkin didn't mention his recently deceased mother or ask to see his father or brother or sister.

At first there weren't any serious reasons for his alienation from the parental hearth. As a child, Pushkin was fat (obese, according to his sister), clumsy, inactive. But he wasn't picked on any more than anyone else. His education before he entered the Lyceum was unsystematic. His sole success was with the French language, and he read a great deal, of course, in French.

The eighteenth century in Russia had been a time of German influence. At the end of that century and the beginning of the nineteenth, that began to change to French, and the Pushkin family gave in to it completely. Pushkin grew up among the French people and Frenchified Russians visiting his parents' home. His brother Lev Pushkin recollects: "His upbringing almost entirely excluded anything Russian. He heard only the French language, his tutor was French ... his father's library consisted entirely of French compositions." It was bursting mainly with erotic writers of the eighteenth century and French philosophers-all of it read by Pushkin from childhood, promoting his precocity. The Soviet Pushkin scholar Boris Tomashevsky contended that French was a second native language for Pushkin. ${ }^{12}$

Let's make a comparison of Russian and French influences on Pushkin's development. The child began to read and write Russian when he was five or six years old. His granny on his mother's side, Maria Hannibal, herself with poor mastery of Russian grammar, spoke Russian to him. ${ }^{13}$ A priest taught Scripture in Russian to Pushkin when the boy was ten. Before and after that all his educators were exclusively French, as his sister recalls. The family didn't speak in Russian at home. Pushkin studied fencing, and his teachers-Valville and Grisieu-didn't have a clue about the Russian language. Yakov Grot, in the words of the poet's classmate Matyushkin, tells us "when he first came to the Lyceum Pushkin wrote Russian fairly poorly."14 We might add that that probably didn't bother the Lyceum's teachers one whit.

The first known Pushkin autograph was written in French. His first 
verse, written by him at the age of eight, was the poem "La Toliade." Pushkin wrote a lot of poems, all in French, and burned them when his governess laughed at him. The nine-year-old boy composed a comedy in the spirit of Molière and played all the parts himself. He portrayed all his favorite heroes from French novels. These heroes lived in Paris, in the south of France, or in Italy. He was raised on a French literary diet, and this continued even when he read Shakespeare, Scott, Byron, Dante, Goethe, and Hoffmann-because he read all of them in French.

In his brother's words (and it must be agreed that there is a certain amount of exaggeration), by his eleventh year he knew all of the French literary canon. Precisely by means of the French language he grasped world culture. "He was a true expert in French philology and history," his sister claimed, "and mastered that wonderful French style that in his letters would astound even native-born Frenchmen."15

As far as his creative work went, it has already been written that "Pushkin set out as a frank imitator of French poetry." 16 Annenkov noted that "in his early youth, he [Pushkin-Y.D.] wrote only French verse, like his father and in the spirit of his very upbringing." 17 The literary models used by the mature Pushkin to create his works are a frequent topic of scholarly dispute. ${ }^{18}$ A typical model looks like this: the French work- Russian realia - a Russian work by Pushkin. That is to say, Pushkin would superimpose a French (or other European) literary model on Russian events, creating his own work. For Pushkin, European literature was often a more important source of themes than Russian reality, at least until he turned his attention to the documents of Russian history. But even here, Western models of the historical novel lay on his desk, making it easy for him to search out forms. It was precisely the French Enlightenment philosophers and writers who made a European out of someone who came from a semi-enlightened, half-European, half-Asiatic environment.

A considerable number of his surviving letters are written in French. From the age of seventeen he signed his letters and documents "Pouchkine." Reaching his quarter-century, he informed Zhukovsky: "I write in French because that language is businesslike and suits my pen" (X. 111). As a mature master he wrote in French to Chaadayev: "I will speak to you in the language of Europe, I am more accustomed to it than ours" (X. 282). Isn't it strange that Russians have to read the letters of the Russian poet in biographers' translations? He was intimate with French his entire life. "Pushkin, in accordance with his 
upbringing, often and eagerly used French even in conversation with his compatriots," recalls a contemporary. ${ }^{19}$ Like most of the people in his circle, all his life Pushkin lived surrounded by foreign things and foreigners. Everyday objects like furniture, books, jewellery, clothes, wine-all these were imported from Europe or made in imitation of the European. Everything except things imported from the Orient. We tend to forget that Tatyana Larina wrote a letter to Onegin in French, and the novel's author appears in the capacity of translator. "It ought to be said aloud someday," Pushkin wrote to Vyazemsky, " that Russian metaphysical language still exists for us in a wild state. God grant that it improve the way French has (a clear, exact prose languagethat is, a language of thought)" (X. 120).

In his life, Pushkin put on a Russian-style shirt, if ever, perhaps only for fun in the country, when he went to a fair. He could blend in along with the other peasants in this shirt only until the moment when he opened his mouth. No, the force of circumstance made French turn out to be not Pushkin's second, but his first and mother tongue. Later on, the poet became bilingual: the Russian tongue began to predominate in his verse and prose. But if Pushkin hadn't been a master of the French language, perhaps he wouldn't have become the great Russian writer that he was.

It was no accident that the nickname "Frenchman" clung to him from his schooldays. And, years later, he often called himself "Pushkin the Frenchman." ${ }^{20}$ What was he, after all-a man whom zealous racial purists and humorists would call a Frenchified Russian of African stock with distant strains of German, Swedish, and Italian blood? Of course, he was a real Russian man and Russian writer, and that is the most essential of all in this present debate.

That is nevertheless how the poet's French roots and his borrowings from Western literature - very often without any references or comparisons to primary sources-were justified by official Pushkin scholars (why generations of them had to justify these borrowings we hope doesn't become an issue). "It goes without saying that Pushkin didn't imitate Parny, but freely varied a given topic"; "Pushkin wasn't born a copyist; an exact translation was foreign to his nature." And even this: "Turning to foreign writers, he subordinated them to his creative needs." 21

His parents wanted to give him at least a Europeanized education, if not a European one. Two variants were discussed: a Jesuit college in 
Petersburg, and a boarding-school for the privileged run by a Catholic abbott. In the opinion of his relatives, Russian educational institutions weren't prestigious enough, and in fact that was the case. But in 1811 the government decided to open a special educational institution for the children of the elite, with the goal of creating a higher aristocracy of officialdom, as was then done in England and France.

The myth of the Lyceum as the cradle of the patriotic Russian nobility is a separate issue. In practice, everything in the imperial Lyceum, from name to contents, was borrowed from similar institutions already long-existent in the West. The word itself was new to the Russian lexicon, and Pushkin himself discussed how to write it: litsey (from the German lyceum), likey (from the Latin lycaeum), or likeya (from the Greek lykaeon)? A contemporary recalled: "The Lyceum was a completely Western-style institution; foreign magazines were provided for the students." 22

Its teachers were both foreigners and Russians, but even the Russian Lyceum professors had received their education abroad at public expense. Alexander I gave the Lyceum his schoolboy library, consisting mainly of foreign books. The Lyceum was located in Tsarskoye Selo at the imperial palace, so that it looked like part of the tsar's family quarters. This was as a result of the plans of Count Mikhail Speransky, who had proposed to teach members of the imperial family in the Lyceum, making dedicated statesmen out of them. In that way, Pushkin could have been sharing a bench with grand dukes Nicholas and Mikhail, that is, might have become a schoolmate of Nicholas I, who was only three years his senior.

Getting into the Lyceum was something accomplished only through powerful patronage, and that was found. His uncle, Vasily Pushkin, a poet with connections, took his nephew to Petersburg along with his mistress, Anna Vorozheykina. It is possible, though, that he was going with Vorozheykina to Petersburg and took along his nephew. Before that his uncle, while married, had, with an emancipated serf-girl, "gone to Paris and other German cities." ${ }^{33}$ Ivan Dmitriev described Vasily Pushkin's trip to Europe thus:

Friends, sisters, I'm in Paris, I've begun to live, not just breathe... ${ }^{24}$

Higher powers who could use their influence on his behalf were 
invoked in order to get him permission to enter the Lyceum. Amongst those patrons was Alexander Turgenev, then director of the Department of Religious Affairs for Foreign Faiths, subsequently a man very close to Pushkin. After it became clear that members of the imperial family wouldn't be studying at the Lyceum, the criteria for the selection of candidates were lowered. For Pushkin, the entrance examinations proved to be a mere formality, given the boy's good French and suitable patronage.

His parents' worries about being mistaken in not sending him to the Jesuit college soon subsided on their own: two years later that college was closed, and in 1820 the Jesuits were expelled from Russia. Another time was at hand; a period of repression had set in. In our view, Pushkin was lucky. Liberality was minimal in the Jesuit concept of pedagogy. They had implemented a system of auditors and intramural spying of one student on another. There were no peepholes in the students' doors at the Lyceum.

The Lyceum opened in a troubled time. Only months remained before the country was at war with the French, a war in which Russia, having liberated itself, was not only able to avoid falling victim to the French, but, on the contrary, to cross Europe all the way to Paris. After the war, society hastened to live and to restore and develop spiritual strengths and values. The Asiatic mixed with the European: different forms of living, life-styles, languages, customs, things, horses, books, people. Blood got mixed, for in Russian villages a numberless crop of French children was born-and Russian ones in Europe. And ideas, of course.

An intelligentsia was developing in Russia, with its own aspirations and hopes for a better time. These hopes had a foundation. The spokesmen of official opinion exulted in print in the triumph of Russian arms, and the very young Pushkin was susceptible to the general enthusiasm.

But there were also those who realized that a French victory in Russia might have been a genuine blessing. France would not only have demonstrated but introduced into people's lives a higher culture-social, economic, and spiritual. Napoleon could probably have accomplished on the spot what Russia needed another half-century to do: he would have abolished the unproductive system of serfdom and created in Russia a more perfect social order, as he had done in other conquered countries. Hopes for a constitution and human rights - that 
were given birth by the French Revolution, the suppressed and persecuted bases of civilized European democracy under a limited monarchy-would have appeared in Russia. Karl Marx, for example, also considered that victory by the more democratic France over despotic Russia would have been a good thing. For the first Marxist, Napoleon was the disseminator of "the fruits of the French Revolution." Marx saw either republics or Cossacks as alternatives for Europe-inconveniently for Soviet historiography. ${ }^{25}$

Later on, it seems to us, the thought of the blessings of occupation for Russia crept into the matured mind of Pushkin. In the poem "Napoleon," the poet wrote of the role that Napoleon could have played for the Russian empire:

Putting into words the official reaction to Russia's victory, the poet further remarks that Napoleon "gave the Russian people a destiny worthy of their size" (II. 60), even if he was only thinking of military distinction.

Western influences and the role of the better part of educated Russian society that was European-orientated is usually played down in official historical literature. As for the rulers of Russia, they were at all times devotedly patriotic, with the exception, strange as it may seem, of Tsar Alexander I.

Nurtured on the ideas of the French Enlightenment, thanks to his wise foreign mentors, he readily absorbed the axioms of civilized society, notions that were taboo in Russia. When he was fifteen, Alexander married Princess Louisa-Maria-Augusta of Baden, anointed as Grand Duchess Elizabeth. This happened in the year that Catherine the Great became seriously alarmed by the winds of the French Revolution.

At first, Pushkin called Alexander a Jacobin (X. 701), and then an autocrat who could respect humanity and ease the severity of Petrine laws (VII. 242). The Swiss, La Harpe, tutor and in his own way the spiritual father of the tsar, kept the letters of the young Grand Duke Alexander, in which he wrote that he wished Russia to have free institutions and even wanted to get rid of the dynastic inheritance of power. 
La Harpe said that he wanted to make a Marcus Aurelius out of Alexander but the Russian milieu preferred the tsar to be a Genghis Khan. ${ }^{26}$ Young Alexander promised that he would give freedom and a constitution on the Western model to Russia, and then abdicate the throne and enter private life "on the banks of the Rhine" (i.e., in Germany). Later he decided to retreat to America. ${ }^{27}$ The idea of escaping to America took hold of Alexander when he understood that his grandmama, Catherine, wanted to remove her son from the line of succession and make her grandson the tsar. Hearing of this from her, Alexander answered his grandmother with tender thanks but behind the tsaritsa's back said he wanted to evade power. This was the origin of his split personality. ${ }^{28}$

Alexander really did set off for Vienna-not in the capacity of emigrant but already as the tsar-to sign the harsh treaty dividing up Europe. We don't know if any desire to abandon crown, sceptre, and orb and go to America arose in him during his reign. But it is known that he did deeply despise the country that he had to rule.

As a matter of fact, there is no riskier occupation than ruling Russia, and even the most skillful despots prepared a refuge abroad for themselves in case they had to cut and run. Ivan the Terrible negotiated with Elizabeth I, the English queen, about getting asylum in case of turmoil, and was going to marry an Englishwoman. He discussed reciprocal asylum with Elizabeth, but she didn't accept that sort of reciprocity. But she did promise refuge to Ivan.

Several of Alexander's years were an epoch of openness in a benighted country, in a manner of speaking. Laws were softened, the secret police abolished; the nobility breathed European air, received a European education. Enlightened absolutism was nearly at hand, the very thing that Radischev and Novikov, whose names were no longer banned, had argued and suffered for. "The wondrous beginning of Alexander's days," Pushkin later recalled in his "Epistle to the Censor" (II.113), recalled when those days were long gone.

The first existing letter by the sixteen-year-old adolescent was full of a feeling of "love and gratitude for this great monarch of ours" (X. 7). For his performance at the Lyceum anniversary in October 1816 Pushkin added two more stanzas to the prayer "God Save the Tsar" (I. 270). He sincerely believed in the tsar's beneficence. Later, Ivan Turgenev, a distant relative of the Turgenev brothers, called the Alexandrine epoch significant to the development both of Russia and Pushkin. ${ }^{29}$ 
But in those same liberal times for the upwelling intelligentsia, Petersburg remained the capital of a gigantic military empire. Barracks sprang up everywhere, regiments pranced in drill-squares, military careers had prestige, officers were everywhere in the street and at balls, and all over the south of Russia mushroomed military encampments, surrounded by the graves of soldiers flogged to death as an example to the living. Factories cast cannons and wove sails; new military accoutrements were purchased from abroad; at the general staff strategic plans were worked out-urgent ones and ones for the years ahead; the diplomatic machine looked for weak links in the alliances of the foreign powers.

Alexander turned out to be only the temporary owner of this gigantic mechanism that he hadn't created-a governmental superstructure completely suppressing Russian society. The statistics for 1813 are not at our disposal, but the number of Russian soldiers increased gradually from 200,000 under Peter I to four million by the First World Warthat is, twenty times over. By the middle of the last century, the upkeep of the army in Russia took from 45 to 50 percent of all government expenditure. Education received 1 percent. ${ }^{30}$

Russia got involved in so many conflicts that transitions from peace to war sometimes went unnoticed. In the course of the eighteenth century, the country was in a state of almost uninterrupted war. Russian troops ended up in Paris. God forbid that this ever happens again in the future: propaganda will have it that Paris has belonged to the Russians since 1813 and that they have only liberated the city from temporary occupation by the French. The officer and future Decembrist Fyodor Glinka waxes ironic on the subject of renaming the Russians the Northern French.

In our time it has been calculated that, in the course of four centuries, Russia seized on average fifty square kilometers of territory daily. The mature Pushkin cites the solemn utterance of Catherine II: "Were I to live for 200 years, then the whole of Europe would of course be under the Russian sceptre." 31

For centuries, the vital energies of the Russian nation had been directed outwards, to capture foreign lands. And - in contradiction to this historical logic--Napoleon invaded Russia, and not the other way around. Russia experienced the delights of occupation on its own territory. But then the Russian army returned from Europe. Earlier, trips abroad had been the privilege of a comparitively narrow circle of 
people. Now hundreds of thousands of Russians found themselves in Europe, in the same but a different world than Russia, with other traditions, institutions, different cultures.

Officers brought home complete libraries, thereby spreading western spiritual values over Rus. Many people experienced a regeneration of the soul when they came to compare what they had found out with what they encountered on their return home. This led thinking people into opposition.

Gathering together to "talk" was becoming a tradition that had heretofore been unknown. Points of contact between Russia and the West were probed for, and there turned out to be lots of them. Advantages in other religions were looked for. Some Orthodox converted to $\mathrm{Ca}$ tholicism. Freemasonry began to spread, with its precept of service to mankind, to have brothers in every corner of the universe. And Pushkin was as naturally drawn toward these seductive ideas as were many others.

In 1815 an event occurred whose radical nature wasn't clear at the beginning. At the Congress of Vienna after the victory, Russia claimed the right to have a hand in deciding the fate of the other countries of Europe, and Europe peaceably agreed. The role of Russian diplomacy grew on the world stage: a real possibility appeared of frightening others not only with weapons but with the language of negotiation and clandestine influences. In a certain sense, the Lyceum became a school for preparing a diplomatic elite capable of spreading Russian great power ideology under these new conditions.

At this very moment a frost was setting in on the internal politics of the country. Over the course of the following decade, the secret police with its network of informers, censorship, and the repression of dissidents was evolving. An unspoken goal of the activity of the government apparatus was to put the brakes on social progress. It should nevertheless be stipulated that in 1817 this policy hadn't yet swamped the pro-Western orientation of culture and the system of elite education.

The French language of the Lyceum's Pushkin was better than that of his classmates. But, as became clear from his dealings with officers who had just returned from France, a language learned from books with the aid of undereducated tutors turned out to be ponderous and a bit old fashioned. But real French was lively and playful. A French education and real Russian life had even less to do with each other, 
even though Pushkin very rarely had any contact with the way of life of simple people.

Pushkin's delightful compositions about the Lyceum weren't always adequate to the real picture. In essence, the Lyceum was a combination of monastery and military school, in which certain European subjects were taught. Pushkin referred to study in the Lyceum as "incarceration" and as life "under lock and key" (X. 8). Count Modest Korf recalled that there was never any kind of freedom of movement at the Lyceum. Students' rooms were called cells. Offences were punished by being made to kneel. Once Pushkin was made to kneel for two straight weeks-during morning and evening prayers. ${ }^{32}$

It was said that in six years of studies only two students were permitted to go to Petersburg, by reason of their parents' serious illness. During the first three or four years, students weren't even allowed to go out into the garden alone. When visiting, parents could be with them only in the common room or on the common walk. Personal books were taken away from the students instantly. Writing was also prohibited. They wrote on the sly. Later, it is true, they were allowed to keep books, to write, and even to publish self-penned magazines (apologetics, of course), and, it goes without saying, these activities were monitored. A ban creates a spiritual deficit, and it would have been no wonder if the students of the Lyceum, left unmonitored, had rushed into prohibited activities with the full maximalism of youth.

But the Lyceum was also something more than just a hybrid of monastery and military school. The spirit of Western liberalism was reflected in its program, saturated with subjects that you and I would enjoy studying. These were Scripture, ecclesiastical history, languages ancient and modern, foreign literature, general history with particular attention to the preceding three centuries, moral philosopy (a strangesounding term in our day, as if immoral philosophy were a subject as well; although now we are aware that a half-century later, it did come to pass). And even more-logic, physics and geography, statistics both native and foreign (essentially elements of sociology), political economics and finance, natural law (meaning human rights), private and public rights, civil and criminal law, pure and applied mathematics, field fortification and artillery, and, finally, fencing.

To this it should be added that the best writers and scientists, including foreigners, were frequent visitors. The emperor's dual patronage-official and personal-and the trusteeship of the reigning family 
replaced the students' absent parents. In a dark corridor, Pushkin grabbed and pinned against a wall Princess Volkonskaya, a cranky old spinster, mistaking her for a chambermaid. In one version, the tsar said that he would be Pushkin's defense attorney; in another, the sovereign ordered Pushkin flogged. Later the young poet received a gold pocket watch and chain from the Dowager Empress Maria for composing an ode in honor of Prince Oransky. According to legend, Pushkin crushed the watch under his heel-which was, in the view of some post-October Pushkinists, testimony to the poet's antimonarchical and revolutionary convictions.

His nicknames changed. "Frenchman," the most neutral of all, became an insult during the war with the French. ${ }^{33}$ The recollections of Pushkin's classmate and subsequent neighbor M. A. Korff, from which this information is taken, were published in abridged form in 1974 and then completely expunged from the 1985 republication of the baron's memoirs. As if foreseeing this, Korff said, "he who would even now be brave enough to reveal Pushkin's moral life to the public would be accounted nearly an enemy of the fatherland and its glory." ${ }^{34}$ Another of Pushkin's nicknames, "Ape," was possibly associated with his fidgeting and a specific facial expression. Griboyedov later called him "Monkey." A third nickname-_"Ape-and-Tiger-Mix"-reflected his unrestrained temperament. His Arzamas colleagues called him "Cricket," a sobriquet more appropriate for a chatterbox, and saying a lot about his talkativeness. "I am stupid and ugly," he joked in his poems, and enthusiastically drew his own profile over and over. ${ }^{35}$

Pushkin's successes couldn't compete with those of his serious contemporaries, and compulsion possibly furthered his development. His knowledge of French wasn't enough, even though he was second in this language. He mastered Latin, but his knowledge of ancient literature was never any better than that of others': many turned out more erudite. After a year at the Lyceum, Pushkin was ranked only twentyeighth (initially ranking fourteenth). Even in verse composition (part of which he wrote in French) he had competitors who were more successful.

His interests during this period were typical of a teenager: reading, mischief-making, and discovering the worrisome delights of the fair sex, which he describes in two languages in two ways: in elegant literary associations and in rough-hewn Russian. "My head is filled with only you ..." his surviving poem "To Natalya," is to a serf- 
actress (I. 9). With this name he began and ended his game with fate. The young versifier lists here the nationalities he could affiliate himself with: he was an African, a Turk, a Chinaman, an American, a German-almost anyone except, somehow, a Russian. However, he was still only a monk - that is, a Lyceum student. He felt cramped and stifled, surrounded by that monastery. Couldn't that be why the participants described in another poem ("The Monk"), rushed to Paris, to the Vatican, to Jerusalem ? (I. 14 and 22) The boy-author was already a sceptic:

In the second line, it would be preferable rhythmically in Russian to exchange the first two words' positions (i.e., from zaschitit' nas to nas zaschitit'), but this wouldn't have been important to the young creator. The sense of the poem wasn't his, but borrowed from his reading of Western romantics. As an adult, Pushkin wanted to model his life on two European idols, Napoleon and Byron. The chief issue for him was ambition. Like his idols, the poet sought the world's recognition. $\mathrm{He}$ asked Voltaire to lend him his lyre so that he could become worldfamous. He wouldn't agree to less. But, if necessary, he would gladly compose an ode like "On the Return of His Majesty the Emperor from Paris in 1815," and his uncle was delighted to spread the news of his nephew's poem.

Pushkin couldn't tolerate constraints, calling himself "an unhappy Tsarskoye Selo hermit" who was jerked around by "the mad demon of scribbling," and complaining, "It's a shame to keep a young man locked up." (X. 8) In our time, Abram Tertz (Andrey Sinyavsky) strongly upbraids the boy: "The brilliant and superficial Tsarskoye Selo education...the lack of a strict system, of a clear Weltanschauung, of mental discipline, the omnivorousness and irresponsibility of the author towards then-existing fundamental doctrines." 36 In some sense, this evaluation is quite factual, but considered in terms of an individual's psychological development, it hardly deserves to be considered negative. Quite the opposite. If anyone ever did demonstrate "a clear Weltanschauung" and responsibility in regard to doctrines, it was zealous Young Communists during certain periods of the Soviet state, even if it was mostly for show. 
Obviously, the development of patriotic feeling was the Lyceum's basic official task. A refectory-mate of Pushkin's, Anton Delvig, in his poem "A Quiet Life," utilizing delicate irony attesting to an understanding of the essence of patriotic exhortation coming from above, wrote:

Pushkin was becoming a European. Later Tumansky would describe him as a person "so European in mind, in character, in enlightenment, in poems, in dandyism." 38

The Lyceum's headmaster, Yegor Engelhardt, understood that a wind was blowing from abroad, bringing fresh ideas. Over there a rich spiritual life burgeoned and young people were grasping at its buds. In its very existence, the Lyceum reflected an inherently Russian structure with its contradiction between form and content. The form was adopted from the West, but its Western spirit was expunged. The seeds of Western European enlightenment were planted in the Lyceum garden but the garden was enclosed by a high fence. The Lyceum headmaster noted among Pushkin's deficiencies a French intellect and a passion for satire. The second notion included what we now call carping. We might add that he showed religious skepticism from early on.

\section{Notes}

1. Katenin's memoirs were given to Pavel Annenkov and first published by him: Annenkov, Materialy 1855. Here: Pushkin v vospominaniyakh 1974, vol. I, 183, commentary, p. 477.

2. Ibid.

3. Lotman 1983, 376.

4. Tsyavlovsky 1916.

5. Dieudonne 1996.

6. Teletova 1981.

7. Mayakovsky 1941, 217.

8. Letopisi 1936 , vol. I, 447.

9. Teletova 1981.

10. Milyukov 1918, part I.

11. Pushkinsky sbornik 1899.

12. Tomashevsky 1960, 62.

13. "Vospominaniya o detstve Pushkina so slov ego sestry O. Pavlischevoy." In Letopisi 
Goslitmuzeya 1936, vol. I, 453-4.

14. Veresayev 1936, vol. 1, 64.

15. O. Pavlischeva, as related by Bartenev, "Rod i detstvo Pushkina" in Otechestvennye zapiski, November, 1853.

16. For example, A. Popov, "Pushkin i frantsuzskaya yumoristicheskaya poeziya XVIII veka" in Pushkinsky istoriko-literaturny sb. 1914, vol. 1, 205.

17. Annenkov 1855, vol. I, 6 .

18. A special work was devoted to this by Volpert 1980, 214.

19. Bumashev 1871, no. 4, 25.

20. "Protokol Litseyskoy godovschiny," written by the poet himself: Rukoyu Pushkina 1935.

21. Pronouncement of D. Sharypkin, P. Morozov, et al., Vremennik 1970, 91-5.

22. S. Shevyrev, "Rasskazy o Pushkine" in Pushkin v vospominaniyakh 1985, vol. 2, 49.

23. Letopisi Goslitmuzeya 1936, vol. I, 88.

24. Recollected by Pushkin's sister, O. Pavlischeva, Ibid., 453.

25. Marx, Engels 1959, vol. XIII, 603; vol. XI, 323.

26. V. Glinsky, "Respublikanets pri dvore" in Istorichesky vestnik, 1888, vol. XXXIV, 89.

27. Platonov $1910,624$.

28. Ibid., 623.

29. Turgenev, "Rech po povodu otkrytiya pamyatnika Pushkinu v Moskve", in 1962, vol. 10,300 .

30. Ocherki po istorii 1918 , part 1, 156-7.

31. Citation by Derzhavin 1984, 143.

32. These recollections are cited by Grot 1901, 246.

33. Pushkin v vospomininiyakh 1974, vol. 1, 119.

34. Ibid., 117.

35. Rukoyu Pushkina, 1935, 290.

36. Tertz 1975, 78.

37. Poety pushkinskogo kruga 1983, 454.

38. Letter from F. Tumansky to Pushkin from Odessa, April 12, 1827, in Perepiska 1982, vol. I, 172. 


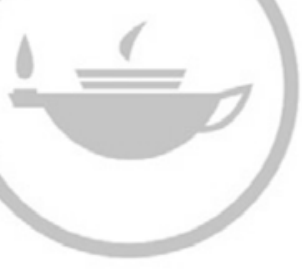

\section{Taylor \& Francis Taylor \& Francis Group}

http://taylorandfrancis.com 